\title{
10. The Fiji media decree: A push towards collaborative journalism
}

ABBSTRACII

This article evaluates Fiji's Media Industry Development Decree 2010 by drawing a link between it and the Singaporean media laws and the collaborative role the Fijian regime claims journalism should play in the nation's development. A number of sections of the Fiji Media Decree are similar to the Singapore Media Development Authority Act 2003 and it contains similar harsh fines and jail terms. The Fiji Media Decree makes provisions for a Media Industry Development Authority and a Media Tribunal, both of which are appointed and controlled by the government. The Authority has wide-ranging powers to search, seize and censor, and refer to the Tribunal incidents which it considers are in breach of the decree. The government minister responsible for administering the decree has a direct say in the make-up of the Media Industry Development Authority and may give directions to the Authority in the performance of its duties and the exercise of its powers. This study explores the powers vested in the government via these two proposed bodies and what they will mean for journalism, freedom of speech and media freedom in Fiji. It also shows the merits of a 'collaborative journalism' model for a developing nation but explains how the design is flawed under the conditions it has been imposed in Fiji.

Keywords: censorship, collaborative journalism, development communications, development journalism, freedom of speech, media law

REGGIE R. DUTT

Bond University, Gold Coast

\section{Introduction}

7 IJI, a small South Pacific island nation, with a multiracial and multicultural population of less than a million, has experienced four coups d'etat since it gained independence from Great Britain in 1970. In 1987, military strongman Sitiveni Rabuka executed the first two coups (Lawson, 2004; Scobell, 1994; Robie, 2009a) and failed businessman George Speight, 
aided by a group of renegade elite soldiers, attempted the third one in May 2000 (Cass, 2002; Lal, 2000; Robie, 2009a; Tedeschi, 2005). Fiji Military Forces commander Frank Bainimarama deposed Prime Minister Laisenia Qarase's elected government in December 2006 in Fiji's fourth coup in just over two decades (Craddock, 2009; Robie, 2009a). Bainimarama claimed he would not abrogate Fiji's acclaimed 1997 Constitution but President Ratu Josefa Iloilo did so in April 2009 after the Appeals Court overthrew a previous ruling and declared the Bainimarama regime illegal. The regime instituted strict media censorship in Bainimarama's second coming as Prime Minister and promulgated the Fiji Media Industry Development Authority Decree (Media Decree) in June 2010 to control the media.

This study explores the Media Decree, the powers vested in the various sections and how it affects media freedom and freedom of speech in Fiji. Parallels with Singapore's Media Development Authority are drawn. The study will consider the development journalism role the government would like the Fiji media to perform and how the law and the situation in Fiji hold up against the other established academic theories of journalism.

\section{Background and overview}

Post-December 2006, the local and overseas media were largely free to criticise and report on the activities of the military government and any opponents of Bainimarama as they had done in the past. Two expatriate newspaper publishers were deported in 2008 and one in 2009 and several journalists were detained and questioned for negative stories about the regime but the military did not stop the media from continuing to publish and broadcast criticisms (Mark, 2009; Robie, 2009b). This was a curious fact of Bainimarama's coup - whereas the tendency of most coup leaders would be to completely muzzle the media and control the flow of information, Bainimarama let the media report relatively freely and be critical of his militarybacked government. Perhaps Bainimarama's ideology was that the mirage of a free media might give him and his proclamations some degree of legitimacy. Whatever the case, local news media were critical of the military regime (Walsh, 2010a), none more so than Fiji's major daily, News Limited owned Fiji Times and the locally owned Fiji Television Limited's news programmes. Following the coup, Qarase filed a case in court, challenging that the overthrow of his government as unconstitutional- the High Court ruled 
against him. In April 2009, the Court of Appeal overturned that ruling, declaring the military government illegal and called on the President to appoint an independent interim government to take the country towards democratic elections. Bainimarama (and the then President Ratu Josefa Iloilo) did not accept the court's decision and abrogated the Constitution and sacked the judiciary (Dodd, 2009; McKenna, 2010).

After the constitution was abrogated, the military government placed 'sulu-censors' in all newsrooms to oversee the news content and ensure that no 'negative' stories about the regime were published or broadcast. President Ratu Iloilo proclaimed himself head of state and appointed Bainimarama as the Prime Minister again (Dodd, 2009). Bainimarama claimed that there would be a new order in Fiji where the media would assist him in his vision of creating a more peaceful, harmonious and progressive Fiji. A public emergency regulations (PER) decree was promulgated to give the military government powers to limit among other rights, the freedom of expression and freedom of speech. Initially, the decree was to run for one month, after which the media would be able to report freely again. However, the regime extended the emergency regulation and announced it would only cease when the government introduced new media laws.

A year later in April 2010, the military regime introduced a draft media decree for consultations and subsequently promulgated it with some changes to the fines, penalties and jail terms. It also changed the make-up of the Media Industry Development Authority and then introduced a provision to appeal against the decision of the Media Tribunal (Sayed-Khaiyum, 2010). The decree incorporated the existing Fiji Media Council Media Code of Ethics and Practice as well as the General Code of Practice for Advertisements, Code of Advertising to Children and a slightly altered Television Programme Classification Code. Part 2 of the decree establishes a Media Industry Development Authority and gives it wide-ranging powers that include censorship of news media content, monitoring compliance with the code of ethics and the powers to require or seize documents from journalists and media organisations. Part 8 establishes the Media Tribunal.

\section{Reaction to the decree}

The international media mainly focussed on Part 7, which regulates foreign ownership of the media in Fiji to just 10 percent of shares. Commentators contended that this move was directed at News Limited-owned Fiji 
Times-Fiji's leading newspaper in terms of circulation and popularity, and a vehement critic of the Bainimarama regime (Cooney, 2010; Dorney, 2010; Robie, 2010a; Walsh, 2010a; McKenna, 2010). The decree was promulgated in late June 2010 giving Fiji Times just three months to sell its shares to Fijian citizens or face closure. News Limited newspapers in Australia led the charge against Bainimarama, claiming that restricting foreign ownership of the media was a restriction of media freedom. The Fiji Foreign Affairs Minister, Ratu Inoke Kubuabola, retorted saying that his Australian counterpart, Stephen Smith, was being 'astigmatic and racist' in suggesting that 'that only an Australian-owned company can purvey press freedom' and that it was 'an insult to other media companies operating in Fiji' (Smith misleading, 2010). The Fijian regime said that it could no longer allow foreign interests to set Fiji's national news agenda. Attorney General Aiyaz Sayed-Khaiyum argued that the Media Decree had ' ... to do with a policy direction that media organisations, like many other countries have regulated, need to be owned by locals because of the powerful nature of media organisations' (Hill, 2010). Sayed-Khaiyum stated that restrictions on foreign ownership of news media was a rule rather than exception, citing examples of Australia, Singapore and the United States, where Rupert Murdoch had to take up US citizenship to build his media empire.

\begin{abstract}
... we are a developing country, there are other many other developed countries that have media restrictions on ownership-the USA does, Singapore does, and I hope that in these next few days when there are discussions on this, that they take into consideration what other jurisdictions are doing-not simply just singling out Fiji. (Fiji to remain, 2010)
\end{abstract}

Sayed-Khaiyum also claimed the government had considered the submissions made by the media industry during consultation on the draft decree in April 2010 and made changes to reflect the submissions in the final document. The international media made little mention of the reductions in the possible fines and jail terms or of the wider representation on the MIDA among other changes announced by the Fijian government. The draft decree had drawn widespread condemnation from media commentators and organisations around the world. Amnesty International said the decree would restrain the media from reporting on government abuses and that the 'Fijian government is giving itself a licence to imprison or bankrupt its critics' (Amnesty says, 2010). 
Reporters Sans Frontières (RSF) said the lack of the mention of press freedom in the proposed decree showed that it was 'designed to enable the military government to tighten its grip on the media - control of media ownership, control of content and control of the dissemination of news within the country' (Julliard, 2010).

Former Fiji-based journalism educator Dr David Robie called the draft law 'deeply disturbing' and that the harsh penalties would ensure there was no return to an independent Fourth Estate (Robie, 2010). Russell Hunter, who had served as editor-in-chief at both the Fiji Times and the Fiji Sun before being deported by the military government, raised concern about the provisions that allowed journalists to be jailed for up to five years and media organisations to be fined up to FJ\$500,000 (equivalent US\$250,000) (Former Fiji, 2010). Political commentator Professor Crosbie Walsh accepted that there was a need for a decree to ensure media responsibility but felt that the military as well any other government could easily abuse the powers provided in the draft decree (Walsh, 2010a). Professor Gary Rodan of the Asia Research Centre at Murdoch University was concerned about the effect of this Singapore-inspired legislation on a free and robust media in Fiji and that, like Singapore, Fiji might also introduce laws that control the reporting of overseas media that are based in the country (Seke, 2010). According to Attorney General SayedKhaiyum, most of the issues highlighted were dealt with during consultation and the changes made in the final promulgated version reflected significant concessions the government made regarding the concerns.

\section{Main features of Fiji media decree}

Under the Decree, the Fiji Media Industry Development Authority is established as a body quite similar to the Singaporean Media Development Authority. The military government has made no secrets about the fact that it has drawn inspiration from Singapore for this media decree-AttorneyGeneral Aiyaz Sayed-Khaiyum claimed the decree 'seeks to create professionalism and accountability in the media sector by setting up transparent processes, adopting practices from other jurisdictions' (Media code, 2010). A comparison of the Fiji and Singapore laws showed similarities in the power vested in the minister responsible for the appointment and dismissal of the Authority (Sections $5 \& 8$ of the Singapore Act compared to Parts 4, 6, 10 $\& 11$ of the Fiji Media decree). Sections 11 and 12 of the Singapore Media 
Act and Parts 8 and 9 of the Fiji Media Decree assign almost identical functions and powers to the Media Development Authority. Singapore's Section 29 and Fiji's Part 17 protect the Media Authority from liabilities. Both laws have the same powers to require documents from journalists and news organisations (Sections $52 \& 53$ of Singapore Act and Parts 26, 27 \& 28 of Fiji Media Decree). The courts are also given similar jurisdictions through Sections 61 \& 62 in Singapore and Parts 81 \& 82 of the Fiji Media Decree.

The Fiji Media Decree differs a little in that it makes use of the existing media codes. It establishes a Media Tribunal to handle complaints that the Authority or even individual complainants refer to it or the Tribunal decides to investigate on its own accord. Parties to a complaint can challenge the Tribunal's final decision in the Fiji Court of Appeal. Such a facility is not provided under the Singaporean law. After the brief consultations it held with the media industry, the Fiji regime reduced the penalties in the final decree from a possible fine of FJ $\$ 100,000$ for individual journalists in the draft decree to FJ\$1000 (US\$500), while the jail terms were reduced to two years maximum from the proposed five years maximum in the draft decree. The fines for editors and publishers were similarly reduced from FJ $\$ 250,000$ to FJ\$25,000 while for media companies it was reduced to FJ\$100,000. The reduced fines in the final decree are similar to those imposed by the Singapore Media Act. Overall, the decree was drafted in the same vein as the Singapore Act and many of the sections were copied word-for-word by the Fiji decree. The main features of the Fiji Media Decree are outlined below.

Part 2 of the Decree creates the Media Industry Development Authority of Fiji, which will have a chairperson and five other members. All six members will be appointed by the minister responsible for the administration of the decree. Apart from the chairperson, the five other members include the solicitor general, a representative each of consumer affairs, children's interests, women's interests, and a person from the media industry. The MIDA has powers to enforce the media codes of practice and the advertising and programme classification codes; to monitor news content for any material that is deemed against 'national' or 'public interest' or which creates communal discord; to accept complaints against the media, investigate and refer them to the Media Tribunal and to advise government on media-related matters.

Part 3 of the Decree incorporates the Media Code of Ethics and Practice, the General Code of Advertisements, the Code for Advertising to Children 
and the Television Programme Classification Code. These codes have existed previously as the Fiji Media Council Codes and apart from the Television Programme Classification Code, which has seen a few minor changes to encourage greater local content, the other three codes have been used unaltered. In essence, what was previously an unenforced media self-governing document has now been brought into law. An addition is a ban on political advertising.

Part 4 deals with content regulation stating that the media must not produce material that is against public interest or order, national interest or anything that would create communal discord. None of the terms are defined or any parameters suggested which makes this part open to interpretation by the MIDA or the government. Any offences related to content regulation could see the media organisation face a maximum FJ $\$ 100,000$ fine or in the case of editors and publishers, up to FJ $\$ 25,000$ fine and/or maximum two year jail term.

Part 5 gives the MIDA the power to investigate suspected infringements of the provisions of the decree, powers to enter, search and seize documents under warrant, and to require documents and information which the Authority needs for its investigations. But this section also limits the MIDA's ability to seek the identity of sources, especially in relation to cases of corruption and abuse of office. The MIDA would need to apply to the Media Tribunal for a warrant and show reasonable grounds for the warrant to be granted. Anyone who fails to produce the required documents; who obstructs the MIDA's access to search and seize documents; destroys or falsifies documents; or who provides false or misleading information, will face a maximum fine of FJ\$10,000 and/ or up to two years in jail.

Part 6 sets out the registration process for media companies-sworn affidavits need to be lodged with the MIDA for all media organisations in Fiji. For newspapers and print media, the requirements are the names of the proprietor, the publisher and printer; for broadcast media, details of the proprietor, location of stations, repeater stations and production buildings, as well as frequencies and coverage maps.

Part 7 sets out the features of media organisations and the ownership rights of locals and foreigners. Foreign ownership is limited to 10 percent of beneficial shares. Cross-media ownership is allowed but limited to 25 percent non-voting shares in organisations in the same medium; while the restriction is 5 percent non-voting shares in organisations in a different medium. Infringements to both parts 6 and 7 fines of up to FJ\$10,000 and/or maximum two years jail time, while companies can be fined up to FJ\$100,000. 
Part 8 establishes the Media Tribunal, which will be made up of a chairperson, appointed by the President on the advice of the Attorney General. The chairperson would need qualifications to be a judge and will have powers to hear and determine complaints referred to it by the MIDA, or those directly received from complainants. It will also adjudicate any breaches of the media codes. The Tribunal can be given policy directions by the Attorney General but is expected to maintain independence from government and any other person.

Part 9 sets out the process through which the MIDA can receive and act on complaints and also sets out the recourse available to complainants if the MIDA decides to summarily dismiss any complaints. It also empowers the MIDA to act and investigate a matter on its own accord if it has to do with media organisations failing to meet provisions of this decree or for infringements relating to the media codes.

Part 10 outlines the proceedings before the Tribunal and the procedures that are to be followed during the referral and hearing of complaints and media disputes. The decisions of the Tribunal are binding, but the decree makes an allowance for complainants and/or defendants to seek redress in the Court of Appeal if they are unhappy with the Tribunal's decision. Media companies are only allowed the right to appeal the Tribunal's decision if the ruling is an award of more than FJ\$50,000. The Tribunal can fine individual journalists up to a maximum of FJ $\$ 1000$ for transgressions under the decree, editors and publishers up to $\$ 25,000$ while media organisations can be fined up to a maximum of $\$ 100,000$.

Part 11 contains miscellaneous sections, parts of which allow the minister to make directives during emergencies, the jurisdiction of the magistrates and high courts, the limitation of commencement proceedings to six months from the date of alleged offence and the repeal of the Registration of Newspapers Act and the Press Corrections Act.

\section{Analysis: Media theories and journalism models}

In 1956, Fred Siebert, Theodore Peterson and Wilbur Schramm developed their four theories of the press - the authoritarian, libertarian, communist and social responsibility models, stating that the 'the press always takes on the form and coloration of the social and political structures within which it operates. Especially, it reflects the system of social control whereby the relations of individuals and institutions are adjusted' (Siebert, Peterson \& Schramm, 1956, as cited in Christians, Glasser, McQuail, Nordenstreng \& 
White, 2009, p. 3). Christians et. al. (2009) have restructured the four theories of press into four roles of journalism: the monitorial role, the facilitative role, the radical role and the collaborative role. Monitorial journalism is similar to the watchdog role, scanning the public and government sphere for information and events, which are then reported, based on what might be of interest to the public. The facilitative role builds upon the reporting functions with the idea that journalism will support and strengthen civil society and its activities. The radical role gives the media a critical voice in society, whereby it can openly challenge government and any authority with its own perception of the truth. The collaborative role creates a relationship between the media and the sources of power in which the media is expected to contribute towards the political and economic successes of a society.

Prior to April 2009, the Fiji news media held a radical role, in which according to Christians et. al. (2009, p. 31), the media act as a 'voice of criticism in their own right' and 'provide a platform for views and voices that are critical of authority and the established order'. Following the military takeover of government in December 2006, the Fiji media continued to play the radical role, openly criticising the military establishment and giving voice to the opposition forces like the ousted prime minister Laisenia Qarase (see Kikau, 2007; Army wrong, 2007; Vunileba, 2008; Qarase rejects, 2008). Walsh (2010a) contends that the Fiji Times gave anti-Bainimarama government spokespeople four times the opportunity it afforded spokespeople from the government.

It could be argued that it is the execution of the radical role by the Fiji media, which might have triggered the military regime to focus its attempts on suppressing and limiting media freedoms (Robie, 2008, p. 109). When Fiji's 1997 Constitution was abrogated in April 2009, the military-backed government not only limited the freedoms enjoyed by the media, but by introducing the new media decree, it has tried to fundamentally change the role the media plays in the greater Fiji society (Bainimarama, 2009). Bainimarama called on the media to play a 'collaborative role' and to support him in his vision of achieving peace and harmony in Fiji. Christians et al. (2009) set out the conditions in which governments might require this role of collaboration:

Even today, under certain circumstances, the news media are called on to support civil or military authorities in defence of the social order against threats of crime, war, terrorism, and insurgency. The claim 
to media cooperation can be more general and involve demands that journalism support authority. In developing societies, journalism may be directed to serve particular developmental goals. (p. 31-2)

Theoretically, this role should not be imposed on the media. The 'collaboration' should come from acceptance of the role from within the media organisations' structures and values. Instead of an imposition, the media should see it as their role to work with the authorities to achieve the specific development results that a society or nation might want to achieve. According to George (2007), Singapore is one nation that has been able to engender this level of cooperation from its news media industry through the use of 'calibrated coercion'. This coercion has been achieved using a combination of stifling media laws and its implementation through a court system that has rarely ruled against the government on media matters (Article 19, 2005; Tey, 2008; Christians et. al., 2009). The Singapore media's role is one of social responsibility with the aim of assisting the development of the Singapore nation. Like Fiji, Singapore was also a British colony, had a fractious multiracial population and at independence, faced similar challenges in creating peace, unity and national prosperity. The People's Action Party has managed to form the successive governments since 1959 with the aid of a compliant media industry that does little to question the status quo. George (2007, p. 136) and Vasil (2000, p. 233) have argued that this has given Singapore a level of political stability from which the government has pursued and attained the nations economic success.

Over the past four decades, Singaporeans have been led to believe that their model of news media suits the interests of their wider society and that the media's role is to support the government its quest to promote harmony, solidarity, tolerance and prosperity, rather than to question the existing social, political and economic structures. In Fiji, Bainimarama wants to achieve a similar application of development journalism to that in Singapore - that is for the media to assist the state in building and sustaining a national agenda for peace, stability, progress and prosperity (Bainimarama hails, 2010; Bainimarama, 2009). His efforts to impress this model upon the Fiji media between December 2006 and April 2009 were met with stiff resistance (Bainimarama urges, 2008; Bainimarama defends, 2007; Julliard, 2010). Between April 2009 and April 2010, when the Bainimarama regime ruled with the Public Emergency Regulations, it found the Fiji Sun newspaper 
warming to its idea of development journalism - but the Fiji Times ignored most government-related stories (Walsh, 2010a). Christians et al. concede that the idea of collaboration is not popular as might be perceived as impinging on the independence of the media, but it can be legitimate if there are grounds of necessity.

The collaborative role, however, is scarcely represented at all in the literature on press roles, largely because it goes against the libertarian and professional journalistic grain and expresses some truths that many would rather leave unsaid. (2009, p. 127)

Christians et al. posit that articulating and accepting a viable collaborative role for the media requires a greater understanding of the relationship and arrangements between the media and the state "than most Western views of press freedom permit' (p. 217). Simplifying the relationship between media and the state to the adversarial does not work in every situation, as different political, social and cultural environments need to be contextualised. Bainimarama's version of development journalism qualifies for the collaborative role devised by Christians et al. (2009, pp. 198-9), but only as 'collaboration as compliance' which the authors believe is the 'weakest and least compelling rationale for a collaborative role for the media'. In the table below, Christians et al. show that there are three levels of collaboration - collaboration as compliance, collaboration as acquiescence and collaboration as acceptance.

Given that the Bainimarama government has promulgated a decree to promote development journalism in Fiji, under the collaboration model, it would be classed as 'collaboration as compliance' and 'coercion'. This condition exists in Fiji because the media has been subjected to a law that it does not necessarily agree with and the industry has no option but to comply with the law because it governs the industry's existence. If the industry were in agreement with the law, the condition then would change to 'collaboration as acceptance'. Christians et al. (2009) state that 'collaboration as acceptance' provides the best model for co-operation between the government and the media. Examples of collaboration as acceptance can be seen during times of war or terrorism such as the September 11 terrorist attacks on the United States or during hosting or bidding of a major event such as the Olympics in a country. The media usually unites in a patriotic bind with the government and other agencies for the greater good of the nation. While this level of collaboration is issue-based, it can also be a useful model for development journalism (Christians et al., 2009; Manning, 2009). 


\begin{tabular}{|c|c|}
\hline \multicolumn{2}{|c|}{ Collaboration as compliance } \\
\hline Coercion & $\begin{array}{l}\text { No choice in the matter; a law or some other form of overt control } \\
\text { compels the media to cooperate. }\end{array}$ \\
\hline Apathy & $\begin{array}{l}\text { Indifference or ignorance; cooperation exists in the absenceof any } \\
\text { serious attention to it. }\end{array}$ \\
\hline Tradition & $\begin{array}{l}\text { Custom dictates action; journalists accept history as a justification for } \\
\text { cooperation. }\end{array}$ \\
\hline \multicolumn{2}{|c|}{ Collaboration as acquiescence } \\
\hline Pragmatic & $\begin{array}{l}\text { Cooperation is unappealing but inevitable; journalists avoid coercion } \\
\text { and acceept their fate }\end{array}$ \\
\hline Instrumental & $\begin{array}{l}\text { Cooperation is unappealing but instrumentally useful; journalists } \\
\text { accept some kind of trade-off }\end{array}$ \\
\hline \multicolumn{2}{|c|}{ Collaboration as acceptance } \\
\hline Practical agreement & $\begin{array}{l}\text { Given what is known about particular circumstances, journalists } \\
\text { judge cooperation to be right or proper. }\end{array}$ \\
\hline $\begin{array}{l}\text { Normative agree- } \\
\text { ment }\end{array}$ & $\begin{array}{l}\text { Given all that needs to be known about these circumstances, } \\
\text { journalists judge cooperation to be right and proper. }\end{array}$ \\
\hline
\end{tabular}

Source: Adapted from Christians et al 2009, p. 199

Collaboration in the tradition of development journalism usually involves a partnership with the state, though not always a formal one, a relationship premised on a commitment by the press to play a positive role in the process of development. From this perspective, responsibility tempers press freedom; journalists can question, even challenge, the state, but not to the point where they undermine a government's basic plans for progress and prosperity. (Christians et al., 2009, pp. 200-1)

The Fiji media, though is not without choices about whether or not to participate in Bainimarama's version of development journalism - the Fiji Times has shown since April 2009 that if it cannot print criticisms of the government, then it would not print praises of it either. The Fiji Media Decree touches every aspect of the industry - from reporting, content regulation and ethics to ownership and complaints and accountability mechanisms. Robie (2010) argued that while 'in a democracy, a media development authority could have its merits ... in a dictatorship it is dangerous. This smacks of blatant and insidious control'. The suspicion among the media and the public of possible of collusion between the Fiji Media Industry Development Authority(MIDA), the Media Tribunal and the government is a defining factor. 
The government appoints officials to both media bodies. At the same time, the government also controls the appointment of judges and magistrates. However much Bainimarama's government claims all these bodies are independent of each other and the government, the stigma of an being unelected military-backed regime will always create doubt among the public and the media about the sincerity of this media governance and accountability system.

Currently, Singapore's media industry can generally be classed into either collaboration as acquiescence or even collaboration as acceptance. George (2007) has argued the initial process was one of 'calibrated coercion' - a phase which is just starting in Fiji. According to Article 19 (2005), Singapore's leaders have used a combination of media laws, defamation suits, ownership and harassment to breed a culture of self-censorship that is prevalent at all levels of the Singapore media industry. Tey (2008) explained that Singapore's leaders have always rejected the libertarian approach to free speech and advocated that the wider interests of the public and the nation override the interests of individuals.

It is a political ideology that places primacy on constructing a political and legal framework conducive to nation-building, economic progress, and social and political stability ... (Tey, 2008)

Rodan (2003) suggests that the hallmark of Singapore's authoritarian governance is the combination of 'legal limits to independent social and political activities ... and extensive mechanisms of political co-option to channel contention through state-controlled institutions'. The use of laws to create the Media Development Authority of Singapore and the appointment of its officers by the government minister serve as an example to Rodan's assessment. According to George (2007), Tey (2008) and Article 19 (2005), these actions were part of the calculated and strategic decisions that Singapore's leaders made in order to ensure their vision of Singapore was carried through.

\section{Conclusion}

The two-way process in the freedom to communicate between government and the public would be seen as an ideal for any country in the world. It would be rare, if not impossible for any one country to achieve what might be termed absolute media freedom. The model many nations end up with is 
a compromise between absolute media freedom and absolute control by the government. Article 19 of the Universal Declaration of Human Rights may bestow the right to freedom of expression and to seek, receive and impart information and hold opinions, but Article 29 (2) of the same declaration places limitations as follows:

In the exercise of his rights and freedoms, everyone shall be subject only to such limitations as are determined by law solely for the purpose of securing due recognition and respect for the rights and freedoms of others and of meeting the just requirements of morality, public order and the general welfare in a democratic society. (UDHR)

But Gallimore (1995, p. 57) asserts that, '[c]ensorship, licensing and restriction of the media are common practices engaged in by despots around the world who fear' that dissidents could use freedom of expression and a free media to whip up public opinion, create an uprising and bring down a dictatorship. Bainimarama's regime views the media decree as utilitarian toolunavoidable for attaining greater media accountability. The regime defines development journalism as the media working with the government and other institutions of society in order to bring about prosperity, modernisation, peace and harmony for the benefit of the whole nation. It wants a commitment by the media to play a positive role in the socio-economic development and advancement of a society or nation. Merrill (1995) states that government leaders who try to achieve political and social viability know that absolute freedom to communicate can place national stability and status quo at risk. As spelt out in the UDHR, governments can choose to place limitations on media freedoms through regulations to maintain the levels of peace and stability and "[c]ontrol, then, is the common — not the exceptional-state of things in the world ..." (Merrill, 1995).

According to Vasil (2000), Singapore's 'limited democracy' might not be the best model for Western nations, but it could provide a lesson for those emerging nations which are trying to find their feet after decolonisation. Bainimarama's regime has set its sights emulating the success that Singapore has had in controlling its media and working together with it towards achieving its vision of internal harmony and economic prosperity. Adapting a model from a country that has a similar colonial history, as well as a melting pot of racial and cultural groups, is something that Vasil (2000) recommends for 
countries for which the Western liberal democratic model has failed to work. Singapore's leaders have worked for the past five decades to achieve the level of 'collaboration' that they currently enjoy with the media industry. Before independence Singapore had a media industry that was similarly vibrant and free as that in Fiji pre-April 2009, but over the years it has been pummelled into self-censorship through submissive tactics and laws. Looking at Singapore's media through the lens of 'collaborative journalism' created by Christians et al. (2009), in theory and in practice, it would appear to be a workable model for the situation that Singapore found itself in following independence. It is a model that the Bainimarama regime has imposed on Fiji. The regime may claim that it has noble intentions (and over time it could well prove so) but the law provides for journalists to be fined or jailed for doing their work, it forces them to reveal sources and it allows the government to control the media authority through appointments. It is a perfect tool to inculcate a culture of self-censorship and to control Fiji's otherwise vibrant news media.

\section{References}

Alley, R. (2000). The coup crisis in Fiji. Australian Journal of Political Science, 35(3), 515-521. Retrieved on 17 July 2010, from Esbco Megafile.

Amnesty says Fiji immunity decree to deflect from abuses. (n.d.). Retrieved on

17 July 2010, from www.rnzi.com/pages/news.php?op=read\&id=52966

Army wrong, says Qarase. (2007, February 3). Fiji Times Online. Retrieved on

17 July 2010, from www.fijitimes.com/story.aspx?ref=archive \&id=56373

Article 19. (2005). Freedom of expression and the media in Singapore. Retrieved on 17 July 2010, from www.article19.org/pdfs/publications/singapore-baselinestudy.pdf

Bainimarama, F. (2009). Address to the nation following appointment of Cabinet. Retrieved on 17 July 2010, from www.fiji.gov.fj/publish/page_14715.shtml

Bainimarama, F. (2007). Roadmap for the return to parliamentary democracy. Retrieved on 17 July 2010, from www.fijilive.com/archive/showpdf.php?pdf=2007/02/ roadmap.pdf

Bainimarama defends media freedom. (2007, May 3). Fiji Times Online. Retrieved on 17 July 2010, from www.fijitimes.com/print.aspx?id=61917

Bainimarama hails media decree. (2010, June 5) Radio Fiji. Retrieved on 17 July 2010, from www.radiofiji.com.fj/print.php?id=28964\#

Bainimarama urges media to be positive. (2008, May 1). Radio Fiji. Retrieved on 17 July 2010, from www.radiofiji.com.fj/print.php?id=10999

Cass, P. (2002). Baptism of fire: How journalism students from the University of the South Pacific covered the Speight putsch and its aftermath. The Round Table, $366,559-574$. 
CCF. (2010). Media laws must protect freedom of expression. Retrieved on 17 July 2010, from www.ccf.org.fj/news_detail.php?news_id=197

Christians, C.G., Glasser, T.L., McQuail, D., Nordenstreng, K. \& White, R.A. (2009). Normative theories of the media: Journalism in democratic societies. Chicago: University of Illinois Press.

Craddock, P. (2009). Fragments from a Fiji coup diary. Pacific Journalism Review, $15(1), 45-65$.

CPJ. (2010). Fiji's draft media decree threatens long-term restrictions. Retrieved on 17 July 2010, from http://cpj.org/2010/04/fijis-draft-media-decree-threatenslong-term-restr.php

Cooney, C. (2010, April 7). Fiji media decree 'extremely worrying'. ABC News. Retrieved on 17 July from www.abc.net.au/news/stories/2010/04/07/2866802.htm

Dodd, M. (2009, April 11). Fiji president sacks judiciary. The Australian. Retrieved on 17 July 2010, from www.theaustralian.com.au/news/world/fiji-president-sacksjudiciary/story-e6frg6so-1225697020509

Dorney, S. (2010, April 24). Fiji Media Decree. Radio Australia Online. Retrieved on 17 July 2010, from www.abc.net.au/correspondents/content/2010/s2881926.htm

Fiji to remain firm on media ownership. (n.d.) Retrieved on 17 July 2010, from http://radiofiji.com.fj/print.php?id=28794\#

Fiji slipping into dictatorship: Qarase. (2006, December 16). Fiji Times Online. Retrieved on 17 July 2010, from www.fijitimes.com/story.aspx?id=53473

Former Fiji Sun publisher says media decree worse than expected. (n.d.). Retrieved on 178 July 2010, from www.rnzi.com/pages/news.php?op=read\&id=52882

Gallimore, T. (1995). Barriers to media development. In J.C. Merrill (Ed.), Global journalism: survey of international communication. ( $3^{\text {rd }}$ ed.). NY: Longman.

George, C. (2007). Consolidating authoritarian rule: calibrated coercion in Singapore. The Pacific Review, 20(2), 127-145. Retrieved on 17 July 2010, from Ebsco Megafile.

Government of Fiji. (2010). Media Industry Development Decree 2010. (Decree No. 29 of 2010). Suva, Fiji: Acting Government Printer. Retrieved on 17 July 2010, from www.fiji.gov.fj/

Hill, B. (2010). We're not silencing critics, says Fiji. Retrieved on 17 July 2010, from www.radioaustralianews.net.au/stories/201006/2939266.htm?desktop

Julliard, J.F. (2010). Open letter to prime minister Frank Bainimarama. Retrieved on 17 July 2010, from http://en.rsf.org/spip.php?page=impression\&id_article=37827 Kikau, R. (2007, April 14). Dictatorship, says Qarase. Fiji Times Online. Retrieved on 17 July 2010, from www.fijitimes.com/story.aspx?id=60691

Lal, B.V. (2000). Chiefs and thieves and other people besides: The making of George Speight's coup. The Journal of Pacific History, 35(3), 281-293

Lawson, S. (2004). Nationalism versus constitutionalism in Fiji. Nations and Nationalism, 10(4), 519-538. Retrieved on 17 July 2010, from Ebsco Megafile Complete. Leo, P. \& Lee, T. (2003). The 'new' Singapore: mediating culture and creativity. Continuum: Journal of Media \& Cultural Studies, 18(2), 205-218. Retrieved on 17 July 2010, from Esbco Megafile Complete.

96 PACIFIC JOURNALISM REVIEW 16 (2) 2010 
Manning, S. (2009). Observer or participator? Diversity challenges for the role of the media profession. Pacific Journalism Review, 15(1), 11-18.

Mark, D. (2009). Newspaper publisher deported from Fiji. ABC Online. Retrieved on 17 July 2010, from www.abc.net.au/pm/content/2008/s2475601.htm

McKenna, M. (2010, June 29). Fiji dictator Frank Bainimarama cracks down on press freedom. The Australian. Retrieved on 17 July 2010, from www.theaustralian.com. au/business/media/fiji-dictator-fran...marama-cracks-down-on-press-freedom/ story-e6frg996-1225885426213

Media code of ethics part of new decree. (n.d.). Retrieved on 17 July 2010, from www.fijilive.com/news/2010/04/03/24828

Media Development Authority of Singapore Act 2002, No. 34 of 2002. Singapore Government. Retrieved on 17 July 2010, from www.mda.gov.sg/.../MDA_of Singapore_Act_Code_of_Practice_for_Market_Conduct.pdf

Media Industry Development Decree $\overline{2} 01 \overline{0}-$ draft. (n.d.). Retrieved from http://kauri. aut.ac.nz:8080/dspace/handle/123456789/3028

Merrill, J.C. (1995). Introduction. In J.C. Merrill (Ed.), Global journalism: Survey of international communication. ( $3^{\text {rd }}$ ed.) New York, NY: Longman.

New media decree part of government reforms. (2010, July 1). Retrieved on 17 July 2010, from www.fiji.gov.fj/index.php?view=article\&catid=71\%3Apress-rel...pon ent\&print $=1 \&$ layout $=$ default\&page $=\&$ option $=$ com_content $\&$ Itemid $=155$

Qarase: let people decide. (2008, August 8). Fiji Times Online. Retrieved on 17 July 2010, from www.fijitimes.com/story.aspx?id $=97257$

Qarase rejects claim on economy. (2008, November 20). Fiji Times Online. Retrieved on 17 July 2010, from www.fijitimes.com/story.aspx?id=106640

Robie, D. (2009a). Behind the Fiji censorship: A comparative media regulatory case study as a prelude to the Easter putsch. Pacific Journalism Review, 15(2), 85-115.

Robie, D. (2009b). Free speech in Fiji [Editorial]. Pacific Journalism Review, 15(1), 5-8.

Robie, D. (2010, April 10). Draft Fiji media decree draconian and punitive. [Web log comment]. Retrieved on 17 July 2010, from http://pacificmediacentre.blogspot. com/2010/04/draft-fiji-media-decree-draconian-and.html

Rodan, G. (2003). Embracing electronic media but suppressing civil society: authoritarian consolidation in Singapore. The Pacific Review, 16(4), 503-524. Retrieved from Esbco Megafile Complete.

RSF. (2010). Proposed decree establishes legal basis for media censorship and repression. Retrieved on 12 April 2010 from www.rsf.org/Proposed-decreeestablishes-legal.html

RSF. (2006). Minister uses tough law to censor Far Eastern Economic Review. Retrieved 30 June 2010, from: http://en.rsf.org/spip.php?page=impression\&id article $=19032$

Sayed-Khaiyum, A. (2010). Commencement of the Media Industry Development Decree 2010. Retrieved on 12 April 2010, from www.fiji.gov.fj

Scobell, A. (1994). Politics, professionalism, and peacekeeping: an analysis of the 1987 military coup in Fiji. Comparative Politics, 26(2), 187-201 


\section{MEDIA FREEDOM IN OCEANIA}

Seke, S. (2010, April 9). Fiji's Singapore-style media model worrying. Retrieved on 10 April 2010, from www.radioaustralia.net.au/pacbeat/stories/201004/s2868064.htm Smith is misleading Australians-Ratu Inoke. (2010, July 1). Retrieved on 10 April 2010, from www.fiji.gov.fj

Tedeschi, M. (2005). Prosecuting in paradise-race, politic and the rule of law in Fiji. Crime, Law \& Social Change, 44,79-109.

Tey, T.H. (2008). Confining the freedom of the press in Singapore: A 'pragmatic press for 'nation-building'? Human Rights Quarterly, 30(4), 876-907. Retrieved on 10 April 2010, from Ebsco Megafile.

Universal Declaration of Human Rights. (n.d.). Retrieved on 10 July 2010, from www. un.org/en/documents/udhr/index.shtml

Vasil, R. (2000). Governing Singapore: a history of national development and democracy. NSW: Allen \& Unwin.

Vunileba, A. (2008, September 27). Qarase queries judgement delay. Fiji Times Online. Retrieved on 10 April, 2010, from http://www.fijitimes.com/story.aspx?id=101964

Walsh, C. (2010a, April 12). The draft media industry development decree-my assessment. [Web log comment]. Retrieved on 10 April 2010, from http://crosbiew. blogspot.com/2010/04/draft-media-industry-development-decree.html

Walsh, C. (2010b, July 3). My re-assessment of the media decree. [Web log comment]. Retrieved on 10 July 2010, from http://crosbiew.blogspot.com/2010/07/ my-re-assessment-of-media-decree.html\#more

Walsh, C. (2010c). Political blogs on Fiji A ‘cybernet democracy' case study. Pacific Journalism Review, 16(1), 154-177.

Reggie J. Dutt is a Master of Journalism student at Bond University. He is a graduate of the University of the South Pacific regional journalism programme and has worked at the Fiji Sun and Fiji Television as a journalist. rdutt@bond.edu.au 
Copyright of Pacific Journalism Review is the property of Auckland University of Technology and its content may not be copied or emailed to multiple sites or posted to a listserv without the copyright holder's express written permission. However, users may print, download, or email articles for individual use.

http://www.aut.ac.nz/depts/commstud/journ/pjrsubs.shtml 